\title{
Kafkasya'da Türkiye, Azerbaycan ve Gürcistan İttifakının Bölgesel Güvenliğe Etkileri
}

\author{
Doğan Şafak POLAT*
}

\begin{abstract}
Öz
$\mathrm{Bu}$ çalışmanın amacı, Türkiye'nin başta Azerbaycan olmak üzere, Gürcistan ile kurduğu ekonomik ve siyasi ilișkilerine askeri boyutu da dâhil etmesinin bölgesel güvenliğe olumlu yönde katkı sağlayacağını ortaya koymaktır. Türkiye, ekonomik ve siyasi alanlarda başlattığı ilişkileri her üç ülkenin de çıkarına uygun olacak şekilde güvenlik alanına taşımak istemekte; böylece Güney Kafkasya'yı bir "güvenlik bölgesi” haline getirmeye çalışmaktadır. Bu sayede bölgede Rusya Federasyonu ve Ermenistan'a karşı da bir denge sağlanmakla birlikte, kendisine doğudan gelecek tehditlere karşı bir ittifak kurulmuş olacaktır. Ayrıca, Türkiye NATO üyeliği kapsamında edindiği bilgi ve tecrübeyi gerek Azerbaycan'a gerekse Gürcistan'a aktararak bu ülkelerin NATO üyeliğine hazırlanmalarına da katkı sağlayacaktır.
\end{abstract}

Anahtar Kelimeler: Kafkasya, Bölgesel Güvenlik, İttifak, Terörizm, NATO.

\section{Turkey, Azerbaijan and Georgia's Alliance in the Caucasus and Its Effects to Regional Security}

\begin{abstract}
The aim of this study is to put forth that including military dimensions to Turkey's development of economic and political relations with Georgia and Azerbaijan in particular will contribute positively to regional security. Turkey, as a regional power, has been developing its economic and political relations with Georgia and Azerbaijan in particular. Turkey, beginning in the political and economic relations to be appropriate in the interest of all three countries, wants to move into the field of security; thus trying to make the South Caucasus "a security zone." In this way, Turkey tries to ensure a balance in the region against the Russian Federation and Armenia and also to establish an alliance against threats from the east. Turkey will also contribute to the preparation for the NATO membership of Azerbaijan and Georgia via transferring its acquired knowledge and experience to these countries.
\end{abstract}

Keywords: Caucasus, Regional Security, Alliance, Terrorism, The NATO.

Özgün Araștırma Makalesi (Original Research Article)

Geliş/Received: 30.01 .2019

Kabul/Accepted: 08.05.2019

DOI: http://dx.doi.org/10.17336/igusbd.519378

* Dr. Öğr. Üyesi, İstanbul Arel Üniversitesi, İktisadi ve İdari Bilimler Fakültesi, Uluslararası İlișkiler Bölümü, İstanbul, Türkiye, E-posta: doganpolat@arel.edu.tr ORCID ID https://orcid.org/0000$\underline{0003-0786-1789}$ 


\section{Giriş}

Kafkasya bölgesi, coğrafi olarak batısında Karadeniz ve Azak Denizi, doğusunda Hazar Denizi, kuzeyinde Maniç Nehri ve bataklıkları, güneyinde İran ve güneybatısında ise Türkiye'nin bulunduğu alanı kapsamaktadır. Ticaret yolları ve göç güzergâhları üzerinde bulunan Kafkasya, farklı kültürlerin de bir araya geldiği kritik bir geçiş noktası üzerindedir. Avrasya'nın en kritik bölgesinde bulunan Kafkaslar, Doğu ile Batı arasında bir köprü oluşturmakta, ekonomik ve siyasi olarak tüm dünyanın ilgisini çekmekle birlikte, güç mücadelesine de sahne olmaktadır (Kantarcl, 2006, s. 3). Bu yönüyle Kafkaslar, tarih boyunca hem doğu ile batı, hem de kuzey ile güney arasında önemli bir koridor vazifesi görmüștür (Hacısalihoğlu, 2006, s. 7). Bölge, Kuzey ve Güney Kafkasya olarak iki bölge halinde anılmaktadır. Kuzey Kafkasya bölgesi, Karaçay-Çerkes, KabardinBalkar, Çeçenistan, İnguşetya, Dağıstan, Osetya, Adigey ve Abhazya'dan oluşmaktadır. Güney Kafkasya ya da Transkafkasya ise bölgenin kuzeyinde, Karadeniz'in kuzeydoğusundan itibaren, Azak Denizi'ni ve Hazar Denizi'ne kıyısı olan Bakü'yü içine alan güzergâh boyunca, batısında Türkiye, doğusunda Hazar Denizi, güneyinde ise İran'ın bulunduğu coğrafya üzerinde, Azerbaycan, Ermenistan ve Gürcistan'ı içermektedir. Ayrıca bu devletler içinde Dağlık Karabağ ve Güney Osetya özerk bölgeleri yanında Nahcivan, Abhazya ve Acaristan Özerk Cumhuriyetleri de bulunmaktadır (Alpargu ve Şahin, 2007, s. 334).

Güney Kafkasya bölgesi bulunduğu stratejik konumu ve yeraltı enerji kaynakları açısından dünyanın en önemli coğrafyalarından birisidir. Güney Kafkasya bölgesinin Türkiye ile kara sınırı olmasına rağmen, Soğuk Savaş döneminde Türkiye'nin NATO müttefiki olması sebebiyle Sovyetler Birliği içerisinde yer alan bölge ülkeleri ile ilişkileri çok sınırlı kalmıştır. Soğuk Savaş sonrası uluslararası sistem radikal bir şekilde değişmiş̦tir. Bu değişime hazırlıksız olan Türkiye, başlangıçta hemen tepki gösterememiș ve bölge ülkeleriyle ilişkilerini istenilen seviyeye getirememiștir. Bu çalışmanın hipotezi “Türkiye'nin doğu sınırına komşu Güney Kafkasya devletleri ile ekonomik, siyasi ve sosyal açısından ilişkilerini geliștirmesi ve ilişkilerini güvenlik boyutunu da kapsayacak şekilde genişletmesi, bölgesel güvenliğe olumlu katkıda bulunacaktır" olarak belirlenmiştir.

Çalışma üç bölümden oluşmaktadır. Birinci bölümde jeopolitik açıdan Güney Kafkasya'nın önemine vurgu yapılacaktır. İkinci bölümde bölgedeki mevcut sorunlara yer verilecektir. Üçüncü bölümde ise Türkiye, Azerbaycan ve Gürcistan ittifakının bölgesel güvenliğe etkilerine değinilerek çalışma sonlandırılacaktır.

\section{Güney Kafkasya Bölgesinin Önemi}

Güney Kafkasya bölgesi, jeostratejik olarak Orta Asya'ya geçiş kapısı olarak görülmesi ve Asya ile Avrupa arasında transit ticaret yollarının kesiștiği yerde bulunması nedeniyle tarih boyunca önemini korumuştur (Kalkan, 2010, s. 17). Ayrıca bölgenin zengin petrol ve doğal gaz kaynaklarına sahip olması önemini daha da fazla artırmaktadır (Alizade, 2015, s. 2). Kafkaslar doğalgaz kaynakları göz önüne alındığında dünyada birinci sırada, petrol kaynakları açısından ise ikinci sıradadır. Bölgenin zengin enerji kaynaklarına sahip bölgesi Hazar Denizi'dir. Dünya petrol rezervinin \% 4'ünün, doğalgaz rezervinin ise \% 6'sının Hazar Denizi'nde olduğu ifade edilmektedir. Azerbaycan'ın petrol üretiminin ve ihracatının \% 75'i Hazar bölgesinden elde edilmektedir (Metin, 2004, s. 80).

Azerbaycan, Ermenistan ve Gürcistan güzergâhının enerjinin Batı'ya ulaştırılmasında bir koridor olması yanında Orta Asya için ihracat güzergâhı da olması 21.Yüzyılın başlangıcından günümüze bölgenin çekişme alanı olmasına yol açmıştır (Dikkaya ve Tığlı, 2015, s. 100). Batı'ya komşu olan Türkiye ise bölgeden elde edilecek 
enerji kaynaklarının dünya pazarlarına ulaștırılmasında stratejik öneme sahip bir köprü konumundadır (Karasu, 2013, s. 1).

Güney Kafkasya'nın üç devletinden birisi olan Azerbaycan, Türkiye'nin hem Orta Asya'ya hem de Güney-Doğu Asya'ya erişiminde kritik bir konuma sahiptir. Azerbaycan, petrol ve doğalgaz kaynakları itibari ile bu bölgede en çok yatırımcı çeken ülke olması nedeniyle bir bakıma ilişkilerin en üst düzeyde olmasını zorunlu hale getirmiștir (Ünsal ve Pamir, 2006, s. 13-16). Son dönemde Hazar Denizi'nin statüsü ve hak sahiplerine göre bölünmesi sağlanmıştır. Böylece 1992 yılından beri Rusya, İran, Azerbaycan, Kazakistan ve Türkmenistan arasında krize neden olan dünyadaki en büyük iç deniz olan Hazar Denizi'nin statüsü sorunu, 12 Ağustos 2018 tarihinde kıyıdaş 5 ülke tarafından imzalanan bir Anlaşma ile çözülmüştür (Koçak, 2018, s. 1).

Küresel enerji devlerinin bölgeye göstermiș oldukları ilgi her geçen gün artmış ve bugüne kadar 15 ülkeden, 25 petrol șirketi, Hazar'da yaklaşık 100 milyar dolar yatırım yapmıștır (İskender, 2007). Bu durum Azerbaycan'a Orta Asya bölgesinde Kazakistan'ı izleyen ikinci büyük ekonomi olması nedeniyle de büyük avantaj sağlamaktadır. Azerbaycan'ın hem doğal kaynaklar hem de konumu itibarıyla jeopolitik önemi $A B$ ve ABD'nin de dikkatini çekmiş ve 1990'lı yılların ikinci yarısından itibaren bölgede faaliyet gösteren Batılı şirketler enerji üretimi ve boru hatlarıyla iletiminde pay sahibi olmaya başlamışlardır. Orta Asya doğalgazının ve Hazar petrollerinin dünya pazarlarına taşınmasında Azerbaycan, Gürcistan ve Türkiye kritik öneme sahiptir. Bölgede inşa edilen Bakü-Tiflis-Ceyhan (BTC) doğalgaz boru hattı 25 Mayıs 2005 tarihinde kullanıma açılmıştır. 3 Temmuz 2007 tarihinde işletime açılan Bakü-Tiflis-Erzurum (BTE) doğalgaz boru hattı, Haziran 2018 tarihinde Trans-Anadolu Doğalgaz Boru Hattı (TANAP)'a bağlanmış ve gaz akışına başlanmıştır. TANAP ile Azerbaycan'ın Hazar Denizi'ndeki Şah Deniz 2 Gaz Sahası ve Hazar Denizi'nin güneyindeki diğer alanlardan elde edilen doğal gazın Türkiye üzerinden Avrupa ülkelerine taşınması planlanmıștır. TANAP, Güney Kafkasya Boru Hattı (SPS) ve Trans-Adriyatik Boru Hattı (TAP) ile birleșerek Güney Doğal Gaz Koridorunu olușturmaktadır. TANAP, 2022 yılında tam kapasite devreye girecektir (T.C. Enerji ve Tabii Kaynaklar Bakanlığı, 2018). Bu durumda Türkiye mevcut konumu ile bir enerji düğüm noktası haline gelmiştir.

Kafkasya bölgesi içinde Karadeniz'e kıyısı bulunan yegâne ülkesi olan Gürcistan, birçok sosyal ve etnik çeşitliliğe sahip olmanın yanında coğrafi konumu itibariyle geçiş noktası üzerinde olması nedeniyle de önemlidir. Ermenistan ve Azerbaycan'ın dünya ile bağlantısı Gürcistan üzerinden sağlanmaktadır. Bölgedeki bir diğer proje de her üç devlet arasında ulaşımı sağlamak maksadıyla 2007'de temeli atılan ve 30 Ekim 2017'de açılan Bakü-Tiflis-Kars (BTK) demiryolu hattıdır (T.C. Dışişleri Bakanlığı, 2018). Bu Proje bir bakıma AB'nin tarihi ipek yolunu canlandırmak ve bölgedeki enerji kaynaklarını ihraç ederek halkının refah seviyesini artırabilecek ülkelerle bağlarını yeniden kurmak amaçlı olarak planlanan TRACECA Projesinin bir ayağını oluşturmaktadır (Üzümcü ve Akdeniz, 2014, s. 1). Projenin amacı Bağımsız Devletler Topluluğu (BDT) ülkelerinin Kafkasya ve/veya Karadeniz üzerinden Avrupa'ya bağlanması olarak açılklanmıștır (TRACECA Genel Sekreterliği, 2010). Bu Projenin bir ayağını oluşturan ve Azerbaycan, Gürcistan ile Türkiye'yi doğrudan bağlayan yaklaşık 838 km'lik demiryolu hattı Demir İpek Yolu olarak da adlandırılmaktadır. Hattın $29 \mathrm{~km}$. si Gürcistan'da, $76 \mathrm{~km}$. si ise Türkiye'de olmak üzere 105 km. si Türkiye'den geçmektedir (Akbulut Özpay, 2018, s. 103). Söz konusu hattın 259 km.si Gürcistan ve 503 km.si ise Azerbaycan topraklarından geçmektedir. Orta Asya'dan gelecek mallar bu hat üzerinden Mersin Limanı'na tașınabilir hale gelmiștir. Amaç Londra'dan Pekin'e kadar kesintisiz olarak gidilmesidir (T.C. Dışişleri Bakanlığı, 2018).

Güney Kafkasya, Avrasya'nın kalbi olarak değerlendirilmekte ve hem Hazar bölgesinden çıkarılan enerji kaynaklarının dünya pazarlarına iletilmesi, hem de Orta Asya ile Orta Doğu'ya yakınlığı açısından sahip olduğu stratejik konumuyla, hem ABD hem de 
Rusya Federasyonu'nun rekabet sahası olmaktadır (Alizade, 2015, s. 7). Soğuk Savaş sonrası elde liderliğini kaybetmek istemeyen ABD, ekonomik ve stratejik bakımdan kritik öneme sahip Güney Kafkasya bölgesinde İran ve Rusya'nın etkinliğini kırmaya çalışmaktadır (Gürses, 2001, s. 250-273).

ABD, Kafkas devletlerinden önce Ermenistan, daha sonra Nisan 1992 tarihinde Gürcistan ve Azerbaycan ile diplomatik ilişkiler kurmuş ve geliștirmiştir. ABD, bağımsızlığını yeni kazanan söz konusu devletlerle siyasi/diplomatik ilişkiler kurmanın ve geliştirmenin yanında askeri/güvenlik desteğini de içeren "İpek Yolu" projesini geliştirmiştir. İpek Yolu projesi, ABD’nin Avrasya'da siyasi ve ekonomik çıkarlarının garanti altına alınması bakımından önemlidir. ABD, Güney Kafkasya'da bulunan devletlerinin süratle demokrasiye ve serbest pazar ekonomisine geçmelerini istemiş ve bölgeyi "yașamsal çıkar alanı" olarak ilan ederek "Kadife Devrimi" desteklemiştir (Yalçınkaya, 2006, s.199).

ABD, bölgeye yönelik hedeflerinin gerçekleştirmek maksadıyla çeșitli yardım programları yoluyla Rusya'yı çevrelemiş ve böylece bölgedeki etkinliğini artırmıștır. ABD, bölgedeki açlk toplumları desteklemekte ve açık pazarları teşvik etmektedir. Bu kapsamda ABD, Güney Kafkasya'ya ABD'li yatırımcıların güven içinde girmelerini sağlayacak ekonomik liberalleşme programlarını da teşvik etmektedir. Ayrıca ABD, desteklediği çeşitli projeler ile bölge ülkelerinde uyuşturucunun ve kitle imha silahlarının yayılmasına engel olmaya çalıșmakta ve bölge ülkelerinin sınır güvenliklerini sağlamaları yönünde katkı vermektedir. Özellikle 11 Eylül terör eylemlerinden sonra ABD, El Kaide ile bağlantılarının olduğu iddia edilen Çeçen militanlarla mücadele etmek amacıyla Gürcistan'ın Pankisi bölgesine asker göndermiş ve Rusya'nın bu bölgede yapması muhtemel operasyonlarına da engel olmuştur (Yalçınkaya, 2006, s. 198).

ABD, bölgenin güvenliğini sağlamak için yardımlar yapmakta ve Hazar Bölgesi Güvenlik Girişimi'ne (Caspian Guard Initiative) de katkı vermektedir. ABD, yaşamsal çıar alanı olarak açıkladığı bölgede etkinliğini daha da arttırmak ve eski Sovyet coğrafyasında kendi hegemonyasını inșa etmek maksadıyla NATO'nun doğuya doğru eski Sovyet Cumhuriyetlerini içine alacak șekilde genişlemesini desteklemiștir. Bu maksatla 1991 yılında Kuzey Atlantik İşbirliği Konseyi (KAİK) oluşturulmuş ve eski Sovyet Cumhuriyetleri ile işbirliği çağrısı yapılmıştır. Bu çağrıya ilk olarak Gürcistan cevap vermiș ve Haziran 1992 tarihinde KAİK'e üye olmuștur. KAİK'in askeri ve güvenlik boyutunu oluşturan ve NATO'ya üye olmak isteyen devletleri hazırlamak maksadıyla ABD’nin de desteği ile Ocak 1994 tarihinde Barış için Ortaklık (BİO) projesi başlatılmıştır. $\mathrm{Bu}$ projeye Rusya'nın yanı sıra üç Kafkas devleti de katılmıştır. Bío projesiyle bölge ülkelerinin Rusya'ya bağımlılığının azaltılması amaçlanmaktadır (Gürses, 2001, s. 272). 1997 yılında KAİK yerini Avrupa Atlantik İșbirliği Konseyine bırakmıștır. 2004 ylında İstanbul'da gerçekleştirilen NATO zirvesinde BİO'nun güçlendirilmesi ve Kafkasya'da temsilcilik açma kararı alınmıştır. BİO’nun yanında Rusya'nın bölgedeki etkinliğine karşı koymak maksadıyla 1990'ların ortasından itibaren kurumsallaşan "bölgesel güvenlik paktı" olan GUUAM (Gürcistan, Ukrayna, Özbekistan, Azerbaycan ve Moldova) oluşturulmuştur. İpek Yolu projesi kapsamında Avrupa-Kafkasya-Asya ulaşım yoluna katkı sağlayan GUUAM üyesi ülkeler ile NATO arasındaki askeri işbirliği, ABD ve BíO üzerinden sağlanmaktadır (Kuzlova, 2005). Bu kapsamda Ukrayna, Gürcistan ve Azerbaycan askeri birlikleri ilk tatbikatlarını 13-19 Nisan 1999 tarihleri arasında gerçekleştirmişlerdir.

Rusya, Güney Kafkasya'da artan ABD etkinliğine karşı bölge devletleriyle işbirliğine önem vermekte ve ABD'ye karşı bölgesel çapta destek bulma arayışındadır. Türkiye ise bölgedeki gruplaşmanın tehlikesinin de bilincinde olarak, Rusya'yı dişlamayan daha gerçekçi bir politika izleyerek Rusya ile ilişkilerini güçlendirmeye çalışmaktadır (Aydın, 2004, s. 18). Rusya ile Türkiye arasında doğalgaz alımı, ticaret, 
turizm, inşaat hizmetleri gibi geniş bir alanda işbirliği içindedirler. Gelișen işbirliğine karşın, iki ülke 2000'lere kadar Güney Kafkasya'da rakip olmayı sürdürmüşlerdir. Rusya, zamanla Türkiye'nin Güney Kafkasya bölgesinde aktif politikalar izlemesinden ve " 21 . yüzyıl Türk yüzyllı”, “Adriyatik’ten Çin Seddi'ne Türk Dünyası” gibi söylemlerinden rahatsız olmuştur. Ayrıca Rusya Türkiye'nin Güney Kafkasya ile Orta Asya'ya açılımını "bölgedeki Amerikan ve NATO girişimlerinin bir uzantısı" olarak değerlendirmektedir (Akgün, 217). Türkiye'nin girişimiyle 2 Nisan 2001'de kurulan ve 2 Kasım 2003'te tüm taraf ülkeler arasında (Türkiye, Rusya Federasyonu, Gürcistan, Romanya, Bulgaristan ve Ukrayna) yürürlüğe giren "Karadeniz Deniz İşbirliği Görev Gücü" (BLACKSEAFOR), 2000 'lerde daha da gelișen ve bölgeye de yansıyan Türk-Rus işbirliğinde önemli bir adım olmuştur. Ayrıca, taraflar arasında uluslararası terörizmle mücadele, ekonomi, Karadeniz Ekonomik İşbirliği (KEI) örgütü ve BLACKSEAFOR gibi geniş bir alanda işbirliğinin altı çizilmektedir. Bunun yanı sıra 16 Kasım 2001 tarihinde New York'ta Türkiye ile Rusya Federasyonu Dışişleri Bakanları arasında "Avrasya'da İşbirliği Eylem Planı" imzalanmış ve Dışişleri Bakanlarına rapor verecek üst düzey Ortak Çalışma Grubu'nun oluşturulması kararlaştırılmıştır. Nitekim 9 Nisan 2002'de Moskova'da gerçekleştirilen Ortak Çalışma Grubu'nun ilk toplantısında, Güney Kafkasya bölgesinde istikrarın sağlanması ve anlaşmazlıkların kalıcı olarak çözümüne katkı sağlamak amacıyla Güney Kafkasya Alt Grubu oluşturulmuştur. Güney Kafkasya Alt Grubu'nun ilk, Ortak Çalışma Grubu'nun da ikinci toplantısı 17-18 Aralık 2002'de Ankara'da yapılmıştır (Kanbolat, 2003, s. 50-52). Böylece Avrasya İşbirliği Eylem Planı ile 1990'lar boyunca bölgede rakip olan Rusya ve Türkiye'nin işbirliğine geçmesi, Güney Kafkasya'daki ABD-Türkiye-Azerbaycan-Gürcistan ve Rusya-İran-Ermenistan bloklaşması göz önüne alındığında önem kazanmaktadır (Sever, 2001, s. 241-242).

Görüldüğü üzere, Sovyetler Birliği'nin dağılması sonrasında Güney Kafkasya'da güç boşluğunu kimin dolduracağı sorusu ortaya çıkmıştır. Gerek Rusya, gerekse ABD bölgedeki etkinliğini artırmak maksadıyla bölge ülkelerini yanına çekmeye çalışmaktadır. Türkiye ise bu stratejik bölgede doğu sınırına komșu Güney Kafkasya devletleri ile ekonomik, siyasi ve sosyal ilișkilerini geliștirerek bölgeyi bir güvenlik bölgesine dönüştürmek için çaba sarf etmektedir.

\section{Güney Kafkasya'da Yaşanan Sorunlar}

Sovyetler Birliği'nin yıkılması ve Soğuk Savașın sona ermesiyle birlikte Güney Kafkasya Bölgesinde ortaya çıkan güç boşluğunu doldurabilmek için Rusya, İran ve Türkiye gibi bölgesel güçler birbirlerine karşı mücadele içine girmişlerdir. Ancak hiç biri tam anlamıyla bölgede etkinlik kuramamıștır. Daha sonra bu mücadeleye ABD ve AB gibi küresel güçler de eklenmiştir. Küresel ve bölgesel güçler, kendi çıkarları doğrultusunda Güney Kafkasya'da bulunan etnik grupları destekleyerek, bölgeyi bu yolla kontrol etmeye çalışmışlardır (Oğan ve Ağacan, 2001, s. 25-27). Aşağıdaki bölümde Güney Kafkasya'da bulunan Azerbaycan, Ermenistan ve Gürcistan'da yaşanan bazı önemli sorunlara yer verilmiştir.

\subsection{Dağlık Karabağ Sorunu}

28 Mayıs 1918 tarihinde Azerbaycan Demokratik Cumhuriyeti kurulmuştur. Haziran 1918 tarihinde ise Osmanlı İmparatorluğu ile üç Güney Kafkasya cumhuriyeti arasında Batum Anlaşması imzalanmıştır. Bu anlașma ile Yukarı Karabağ'ın, Azerbaycan Demokratik Cumhuriyeti içinde özerk, koruma altındaki bir devlet olduğu onaylanmıştır. 1920 yılından itibaren ise Ermenistan'ın bu bölgeyi kendisine bağlama girişimleri başlamıștır. 1921 yılında Ermenistan Yüksek Sovyeti, bölgeyi Azerbaycan Sovyet Sosyalist 
Cumhuriyeti'nden ayrılıp Ermenistan Sovyet Sosyalist Cumhuriyetine katılmasına izin verilmesi hakkında karar almıştır (Alizade, 2015, s. 3). Azerbaycan Yüksek Sovyeti ise SSCB Anayasası'nın 78. Maddesine göre bu değișikliğin kabul edilemez olduğunu belirtmiştir. Bu süreçte bölgenin adı Dağlık Ermenistan Cumhuriyeti olarak değiştirilmiş ancak Sovyet Kızıl Ordusunun 1921 Temmuz ayında bölgeyi işgal etmesi ile dağılmıștır. Temmuz 1923 tarihinde ise Sovyet Sosyalist Azerbaycan Cumhuriyeti sinırları içerisinde Yukarı Karabağ Özerk Oblastı ya da Yukarı Karabağ Özerk Bölgesi kurulmuştur. Yukarı Karabağ'da yaşanan anlaşmazlık 1980’lerin ikinci yarısında Gorbaçov'un açıklık politikası ile tekrar gündeme gelmiștir. Yukarı Karabağlı Ermeniler, bölgeyi Azerbaycan'dan ayırıp müşterek bir kara sınırı bulunmamasına rağmen tekrar Ermenistan ile birleştirmek için yoğun siyasi faaliyetlere bașlamışlardır. Bu çabalar sonuç vermiş ve Yukarı Karabağ'daki Meclisin 1988 Şubat ayında yapmış olduğu oylama ile Sovyet Sosyalist Ermeni Cumhuriyeti ile tekrar birleșmek için karar almıștır. Bu karardan sonra Rusya, Yukarı Karabağ'daki yerel hükümeti devirmiş ve bölgeyi bir Özel İdare Komitesi yoluyla Moskova'nın doğrudan idaresi altına almıștır. Ermenistan'ın ikinci kez Karabağ bölgesini kendisine bağlama girişimi 2 Eylül 1991 tarihinde Karabağ'ın bağımsızlığını ilan edilmesiyle başlamış ve Ermenistan, bu kararın Sovyet Cumhuriyetleri'nin SSCB'den Ayrılması Kurallarına uygun olduğunu belirtmiștir. Azerbaycan Parlamentosu ise 27 Kasım 1991'de Dağlık Karabağ'ın özerklik statüsünü iptal etmiş Azeri kuvvetleri Karabağ'a karşı harekete geçmişlerdir (Demir, 2003, s. 163). Böylece Azerbaycan ile Ermenistan arasında savaş yoğunluk kazanmaya başlamıştır (Cabbarlı, 2007).

1991 yılına kadar Karabağ sorunu Sovyetlerin bir iç meselesiyken, 1992 yılından sonra hem Ermenistan'ın hem de Azerbaycan'ın BM'e ve Avrupa Güvenlik ve İșbirliği Teşkilatına üye olmalarıyla birlikte sorun uluslararası hale gelmiştir (Aslanlı, 2001: 405). Kazakistan devlet başkanı sorunu çözmek için girişimde bulunmuş ancak sonuçsuz kalmıștır. Kazakistan'ın arabuluculuk girişimlerinin başarısız kalması üzerine, 19 Eylül 1992'de Rusya'nın arabuluculuğuyla Soçi kentinde Azerbaycan ve Ermenistan Dışişleri Bakanları görüşmüș ve taraflar arasında 20 Ocak'ta bir anlaşma imzalanmıștır (Cabbarlı, 2004). Ancak tarafların sürekli birbirlerini ateşkesi ihlal etmekle suçlamaları ve Ermenistan'ın Karabă̆ Ermenilerinin de görüşmelere katılmasın da ısrar etmesi neticesinde görüşmelerden bir sonuç alınamamıştır (Aslanlı, 2001, s. 405).

Azerbaycan ile Ermenistan arasındaki gerilim, dış güçlerin açık desteğiyle Ermenistan askeri birliklerinin 26 Şubat 1992 tarihinde Dağlık Karabağ'daki Hocalı kasabasına ağır silahlarla saldırmaları ve savunmasız Azerbaycan Türklerini kasıtlı bir biçimde yok etmeleri ile birlikte en yüksek seviyeye çıkmıştır (Abbaslı, 2011, s. 15-21). Hâkim konumu itibariyle Dağlık Karabağ'ın en önemli bölgesinde yer alan ve bu nedenle Ermeni kuvvetleri için önemli bir askeri hedef olan Hocalı kasabası aylarca top ateși ile vurulmuş; Ermeni kuvvetlerince kasabaya giriş ve çıkışlar kontrol altına alınarak dış dünya ile bağlantısı kesilmiștir. Katliamın yapıldığı tarihlerde 10 bin nüfuslu Hocalı'da 3 bin civarında Azeri bulunuyordu. Ermeni kuvvetleri, bölgedeki Sovyetlerin 366. Mekânize Alayının da desteği ile 25 Şubat'ı 26 Şubat'a bağlayan gece Hocalı kasabasında, 70'den fazla yaşlı, 83 çocuk ve 106 kadın dâhil olmak üzere toplam 613 kişiyi katletmiştir. Hocalı'da meydana gelen bu insanlık dışı katliama Birleşmiş Milletler (BM) ve Batılı devletler ciddi bir tepki göstermemişlerdir. Batılı devletlerin Ermeni katliamına karşı tepkisiz kalmaları ve Rusya'nın Ermenistan'ı desteklemesi neticesinde Ermeni kuvvetleri kısa sürede Dağlık Karabağ bölgesini ve Azerbaycan'a ait bir kısım toprakları işgal etmiştir. Çeșitli devletlerin yanı sıra BM, Avrupa Güvenlik ve İşbirliği Teşkilatı (AGİT) gibi örgütler çatışmaların önlenmesi yönünde girişimlerde bulunmuşlardır. Soruna çözüm bulmak için BM Güvenlik Konseyi'nin karar tasarıları ile 1992'de Fransa, Rusya ve ABD'nin ortak başkanı olduğu AGİT Minsk Grubu olușturulmuștur. "Minsk Grubu" Haziran 1992'de Roma'da görüşmelere başlamış ancak bir sonuç alamamıştır (İşyar, 2006, s. 255). 
3 Nisan 1993'te Azerbaycan'ın Kelbecer ilçesinin Ermeniler tarafından işgal edilmesi sonrasında BM Genel Kurulu tarafindan endișe duyulduğu ifade edilmiş ve AGIKK çerçevesinde barış sürecinin desteklendiği vurgulanmıştır (Cafersoy, 2001, s. 86-87). Ermenistan'ın 7 Nisan 1993'te, Kelbecer'i ve Fuzuli bölgesini işgal etmesi Avrupa Toplulukları (AT) üye ülkeleri tarafından da kınanmış ve BM Güvenlik Konseyi, 30 Nisan günü Azerbaycan-Ermenistan çatışmaları ve özellikle de Kelbecer'in işgali konusunu görüşerek 822 sayılı kararı oybirliği ile kabul etmiştir (İşyar, 2006, s. 261). Daha sonra ABD, Türkiye ve Rusya tarafından, 5 Mayıs 1993 tarihinde taraflara bir çözüm planı sunulmuştur (Cafersoy, 2001, s. 91). Ancak bu planı dikkate almayan Ermeniler, Karabağ'ın doğusundaki Akdam kentini ve civarını 24 Temmuzda ele geçirmişlerdir. Bunun üzerine BM Güvenlik Konseyi 853 sayılı kararı almıștır (Aslanlı, 2001, s. 412). Bölgede inisiyatifi elinde tutmak isteyen Rusya'nın girişimiyle 27 Temmuz 1994 tarihinde taraflar arasında bir ateşkes anlașması imzalanmıștır. Azerbaycan ateșkesi denetlemek üzere oluşturulan BDT barış gücünün yerleștirilmesine yönelik Rus önerisini reddetmiş ve AGİT bünyesinde barış görüşmelerinin sürdürülmesini talep etmiştir. Bölge dışındaki ülkelerin Kafkasya'daki sorunlar dolayısıyla etkinlik kurmalarından rahatsızlı duyan Rusya, AGíT bünyesinde yer alarak aynı zamanda olumsuz gördügü bu gelişmeyi denetlemeye çalışmaktadır. Kısacası 1994 yılında sağlanan ateşkesin ardından başlayan barış görüşmelerinde henüz bir sonuca ulaşılamamıştır.

\subsection{Gürcistan'ın Sorunları}

Sovyetler Birliği'nin çözülmeye başladığı 1980’lerin sonlarında, Gürcistan'ın bağımsızlığa yaklaștığı süreçte Abhazlar ile Gürcüler arasındaki gerilim iyice yükselmiştir. Gürcü lider Zviad Gamsakhurdia'nın Tiflis mitinginde, Tshinvali'nin kontrol edilmesi yönünde yapmış olduğu konuşmanın akabinde, 23 Kasım 1989 yılında 30.000 Gürcü milliyetçisi Tshinvali'nin kontrolü almak için harekete geçmiştir. Bu durum Osetler ve Gürcüler arasında çatışmalara sebep olmuștur. Gamsakhurdia yapmış olduğu bir röportajda; Söz konusu seferberliğin kendisi tarafından organize edildiğini kabul etmiștir (Ozhiganov, 1997, s. 354-355). Gürcistan, Gamsakhurdia liderliğinde 6 Nisan 1991'de bağımsızlığını ilan etmiş; Gürcistan Demokratik Cumhuriyeti'nin 1921 tarihli anayasasına döndüğünü duyurmuștur (Pirtakhia, 2005, s. 4-8).

SSCB'nin Aralık 1991'de resmi olarak dağılmasından sonra Gürcistan Abhazya ve Güney Osetya'nın ayrılmasını önlemek için dengeli bir dış politika izlemeye başlamıştır. Gürcistan, başlangıçta BDT’na girmeye karşı olan bir ülke iken, ayrılıkçı hareketler ve iç savaş sonucu 1993 sonunda BDT'ye girmiş ve Kolektif Güvenlik Anlaşması'nı imzalamıştır (Mert, 2004, s. 53). Bu dönemde Rusya, BDT'nin güvenliğini sağlamak maksadıyla, Gürcistan'da Rus üslerinin kurulmasını öngören bir antlaşmayı Gürcistan ile imzalamıștır. Abhazya ve Güney Osetya liderleri ise Rus-Gürcü askeri işbirliğinin bölgede gerilimi artıracağını ileri sürerek bu antlaşmaya karşı çıkmışlardır. Gürcistan'da ayrılıkçı hareketlerin giderek artması ve ekonomik durumunda kötü olması nedeniyle ülke giderek daha fazla Rusya ile işbirliği içine girmiştir. Ancak Gürcistan'da 1995'te kabul edilen Anayasa ile birlikte sorunlar yeniden başlamıştır.

Gürcistan'ın yaşadığı üç temel sorun mevcuttur. Bu sorunlardan birincisi farklı etnik grupların yaşadıkları bölgelerin Gürcistan'dan ayrılmak istemeleri olarak ifade edilebilir. Örneğin, 1989 yılından itibaren Güney Osetya, Kuzey Osetya ile birleșmek ya da bağımsızlığını ilan etmek için girișimlerde bulunmaya bașlamıștır (Nichol, 2008, s. 4-6). İkinci sorun olarak Cavaheti bölgesinde yaşayan Ermenilerin özerklik talepleri gelmektedir. Üçüncü sorun ise Acaristan Otonom Cumhuriyeti'nin Gürcistan ordusunun ülkeye girmesine müsaade etmemesi olarak ifade edilebilir. 


\subsubsection{Güney Osetya Sorunu}

Gürcistan'ın yaşadığı temel sorunlardan birisi Güney Osetya Otonom Bölgesi'nin, Rusya Federasyonu sınırları içinde bulunan Kuzey Osetya ile birleşmek istemesidir. Gürcüler ile Osetler arasındaki çatışmalar 23 Kasım 1989'da başkent Tshinvali'de başlamış ve Gürcistan çatışmaları bastırmak için sert tedbirler almıştır (Tavkul, 2008, s. 2). Gürcistan 1990 yılında aldığı kararlarla Güney Osetya'nın siyasi özerkliğini teminat altına olan anayasa maddelerini askıya almıştır. Buna karşın 20 Eylül 1990 tarihinde Güney Osetya kendisini Demokratik Güney Osetya Sovyet Cumhuriyeti olarak ilan etmiş ve 9 Aralık 1990'da seçimlere gitmiştir. Gürcistan ise buna tepki göstermiş ve 11 Aralık 1990 tarihinde Güney Osetya'nın özerk statüsünü kaldırdığını açıklamıştır. Güney Osetya'nın asıl amacı, Rusya Federasyonu'na bağlı Kuzey Osetya ile birleşmek olmuştur (Nichol, 2008, s. 4-6).

Bu ortamda Gürcü polisleri ile milli muhafiz birlikleri 5-6 Ocak 1991 tarihinde Güney Osetya'ya girmişlerdir. Çatışmalar gittikçe șiddetlenmiş ve 19 Ocak 1992 tarihinde Güney Osetya'da Güney Osetya Cumhuriyeti'nin bağımsızlığı hakkında referandum düzenlenmiştir. Söz konusu referandumda halkın \%98,2'si bağımsızlık yönünde oy kullanmıştır (Ozhiganov, 1997, s. 361).

Gürcü birlikleri Güney Osetya'ya yönelik bir askeri harekâta girișmek üzereyken, Gamsahurdiya'nın devrilmesiyle bu harekât gerçekleșmemiştir. Gamsahurdiya'nın yerine geçen Edvard Şevardnadze ise, sorunun çözümü için görüşmelerde bulunmak istediğini bildirmiştir. Şevardnadze dönemi, aşırı milliyetçi Gamsahurdiya dönemine göre Osetlerle ilișkiler açısından daha ılımlı bir dönem olmuştur. Bu dönemde taraflar arasında ateşkes ilan edilmiş ve çeşitli anlaşmalar imzalanmıștır (Kumuk, 2004, s. 268).

Ocak 1992'de çatışmalar tekrar başlamış ve Güney Osetya Yüksek Sovyeti 29 Mayıs 1992 tarihinde bağımsızlık bildirgesini açılklamıştır (Yapıcı, 2007, s. 77). 10 Kasım 1996 tarihinde ise Güney Osetya'da parlamento ve cumhurbaşkanlığı seçimleri yapılmıștır (Demir, 2003, s. 192).

23 Mayıs 2004 tarihinde Güney Osetya'da yapılan parlamento seçimlerini ise Gürcüler boykot etmişlerdir (Sekin ve Tekin, 2006: 3). Seçimlerden sonraki ayrllıkçı söylemlerle Güney Osetya sorunu tekrar gündeme gelmiştir. Bu açıklamalarda Güney Osetyalı politikacılar Rusya ile birleşmek istediklerini açıç̧a ifade etmişlerdir (Sekin ve Tekin, 2006, s. 37). Bu durum karşısında Gürcistan, Haziran 2004 tarihinde Güney Osetya bölgesinde görevli Gürcü Barış Gücü asker sayısını 500'e çıkarmış, Gürcistan ise Güney Osetya ile arasındaki sınır bölgesine 2000 Gürcü askerini konuşlandırmıștır (Sekin ve Tekin, 2006, s. 38).

Bu gelişmeler üzerine Güney Osetya Özerk Bölgesi Parlamentosu, 9 Haziran 2004 tarihinde Rusya Federasyonu ile birleşme kararı almıştır (Mert, 2004, s. 62). Buna karşın Rusya, Gürcistan'a bağlı özerk cumhuriyetlerde yaşanan sorunlara müdahil olmayacağını ve Gürcistan'ın iç işlerine karışmayacaklarını açıklamıştır (Kantarcl, 2006, s. 90). Bu süreçte Gürcistan'da gerçekleșen “Gül Devrimi” Rusya tarafından endișe ile karşılanmış ve Rusya Güney Osetya'ya askeri birlik göndermiștir. Bu gelişme üzerine Gürcistan, 13 Haziran 2004 tarihinde Rusya'ya bir nota vermiş ve Güney Osetya'ya gönderilen askeri birliğin geri çekilmesini istemiştir. 12 Kasım 2006 tarihinde gerçekleşen referandumda da Güney Osetya halkının \%99,8'i bağımsızlık yönünde oy kullanmış ve Güney Osetya Parlamentosu, bağımsızlığının tanınması amacıyla 3 Mart 2008 tarihinde Rusya Federasyonu, BDT, BM ve AB'ye çağrıda bulunmuştur (Ertaş, 2009).

Güney Osetya, Gürcistan'dan fiilen bağımsız olarak, kendi çabasıyla ve Rusya ile Kuzey Osetya'nın yardımları ile varlığını devam ettirmektedir. Güney Osetya Cumhuriyeti, 2006 yılından bu yana 13 yıldır bağımsız olduğunu ifade etmesine rağmen diplomatik olarak henüz hiçbir devlet tarafından tanınmamıștır. Rusya ise Abhazya ve Güney Osetya 
sorunlarını Gürcistan'a karşı koz olarak kullanmaktadır (Tavkul, 2002, s. 82). Henüz çözülmemiş olan bu sorunlar Gürcistan'ın NATO ve AB üyeliği için de büyük bir engel teşkil etmektedir. Bu sorunlar sebebiyle 2-4 Nisan 2008 tarihleri arasında Bükreş'te gerçekleştirilen NATO Zirvesi'nde NATO’nun kapıları Gürcistan için açılmamıştır.

\subsubsection{Abhazya'nın Statüsü Sorunu}

Bölgedeki bir diğer sorun da Abhazya'nın statüsü ile ilgilidir. Gürcistan sınırları içinde bulunan ancak coğrafi olarak Kuzey Kafkasya'nın bir parçası olan, Abhazya Özerk Cumhuriyeti bağımsız bir devlet olmak istemektedir (Alizade, 2015, s. 4). Karadeniz'in kuzeydoğusunda yaşayan Abhazlar bulundukları bölgenin dağlık olması nedeniyle istilalara karşı korunmuşlar ve çevre ülkelerde meydana gelen olaylardan fazla etkilenmemişlerdir (Kaşıkçı ve Yılmaz, 1999, s. 134). 1989 yılında gerçekleștirilen Lıhnı Toplantısı sonrasında açıklanan Lıhnı Deklarasyonu'nda Abhazlar kendi kaderini tayin hakkı yanında bașka taleplerde de bulunulmuștur. Ancak nüfusun \%17'sini oluşturan Abhazlar Abhazya'da azınlık durumundadırlar. Gürcistan tarafından 1989 Lihnı Deklarasyonu'nun reddedildiği açıklansa da Abhazların Gürcistan'daki protestoları giderek daha fazla şiddetlenmiştir (Koçoğlu, 2001, s. 19). Gürcistan'ın 1991 yılında bağımsızlığını kazanmasıyla birlikte Abhazların da Gürcistan'a karşı bağımsızlık talepleri başlamıștır (Kumuk, 2004, s. 262). Bu dönemden itibaren Gürcistan ve Abhazya arasında karşılıklı kararlar alınmış küçük çaplı çatışmalar yaşanmıştır (Karayel, 1998). 1992 yılında "Kılıç" adlı askeri operasyonla Gürcistan bölgenin kontrolünü eline geçirmiștir (Kumuk, 2004, s. 262). Ancak Rus askeri desteği altında Kafkasya Halkları Konfederasyonu adlı gönüllü birliklerin ve Ermeni Bagramyan Tugayı'nın Gürcistan’a karşı savaşması neticesinde Gürcistan kontrolü kaybetmiştir (Kumuk, 2004, s. 263). 1991'de bașlayan silahlı çatışmalar devam ederken, Osetya sorununu firsat bilen Abhazya 1992'de bağımsızlığını ilan etmiştir (Elvan, 2006, s. 4).

1992-1993 yılları arasında çeşitli ateșkes anlaşmaları imzalanmışsa da bu anlașmalara pek uyulmamıștır. Son olarak Eylül 1993'te Gürcistan askerlerini Ingur nehrine kadar sürerek bugünkü sınırı belirleyen zaferi elde eden Abhaz tarafı fiili olarak Gürcistan kontrolünden çıkmıştır. Kasım 1994'te Abhazya Meclisi kabul ettiği yeni anayasa ile egemen bir devlet olarak "Abhazya Cumhuriyeti"nin kurulduğunu ilan etmiștir (Kumuk, 2004, s. 268). Gürcistan hükümeti tarafından egemenlik ilanı kınanmış; Rusya ise Gürcistan'ın toprak bütünlügünü tanıdığını açıklamıştır (Karayel, 1998). Ocak 1996 yapılan BDT zirvesinde Gürcistan'a katılıncaya kadar Abhazya'ya karşı ekonomik yaptırımlar uygulanması kararı alınmıștır (Taștekin, 2002, s. 6).

BM destekli barıș görüşmeleri 1997 Temmuz ayında yeniden Cenevre'de başlamış; Kasım 1997'deki Cenevre toplantısında da taraflar haftada bir toplanıp ateșkes durumunu görüşecek İşbirliği Konseyi ile mülteciler ve ekonomik, insani sorunlarla ilgilenecek alt-çalışma grupları oluşturmuşlardır. Abhazya, Rusya ve Gürcistan'ın Gürcistan içinde federal bir birim statüsünde olma önerisini kabul etmemekte; Gürcistan ile eşit statüde olmak istemektedir. Temmuz 2006'da Gürcü Parlamentosu tüm Rus barış gücü birliklerinin çıkması için karar almış, ancak bu karar gerçekleşmemiştir. Ağustos 2008'de Osetya nedeniyle Rusya ile Gürcistan arasında savaş çıkmıștır. Bu dönemde, Abhaz güçleri Kodori vadisine taarruz etmiş ve Gürcü kuvvetleri geri çekilmek zorunda kalmıştır. Sonuç olarak Abhazlar tam bağımsızlık talep etmektedirler. Gürcistan ise Gürcistan'ın toprak bütünlügünün muhafazasını isterken federasyon ve konfederasyon fikrine sıcak bakmaktadır. Dönemin BM Genel Sekreteri Boutras Gali'nin barış görüşmeleri sırasında söylediği gibi Abhazya sorununun çözümü için gereken anahtar Rusya'nın ellerindedir (Elvan, 2006, s. 6). Bu iki devleti kontrol altında tutan Rusya bir adım atmadıkça herhangi bir anlaşma söz konusu olmayacaktır. 


\subsubsection{Acaristan Sorunu}

Acaristan, Türkiye'nin kuzeydoğusunda, Artvin ile Ardahan illerine komşu ve Gürcistan'ın güneybatısında 1921'de Kars Antlaşması ile kurulmuş olan özerk bir cumhuriyettir (Demir, 2008). Acaristan'ın Türkiye sınırında yer alması coğrafi olarak bölgeyi kısmen Rus müdahalelerinden korumuştur (Elvan, 2006, s. 7). 1990’lı yılların ilk yarısında, Gürcistan'da çeşitli çatışmalar ortaya çıkmıştır. Hristiyan Gürcüler ile Müslüman Gürcüler arasında toprak iddialarının artması yeni çatışmalara yol açmıştır. 1991 yılında, Müslüman halkını "Hristiyanlaştırma" ve "Acaristan'ın özerkliğini kaldırmaya" yönelik politikalara karşı gösteriler başlamıștır (Alizade, 2015, s. 6). Bu dönemde Acara Özerk Cumhuriyeti, Gürcistan'ı ekonomik olarak güç duruma sokan bir politika izlemeye bașlamıștır. Batum limanı ve Sarp Sınır Kapısını elinde tutan Acaristan devlet başkanı Aslan Abashidze, gümrük vergilerini ve halktan toplanan vergileri Tiflis'e aktarmak yerine Tiflis aleyhine kendi otoritesini güçlendirmek için kullanmıștır (Elvan, 2006, s. 7). Ayrıca Abashidze, merkezi yönetimden bir askeri müdahale gelmesin diye bölgeyi ülkenin kalan kısmından tamamen kopartmıştır. Buna karşın Rusya bölgeye müdahale etmiş ve Abashidze 6 Mayıs 2004'de Batum'dan Rusya'ya kaçmıştır (Mert, 2004, s. 59). Böylece sorun bir bakıma çözülmüş ve Batum fiilen Tiflis'e bağlanmıştır. Rusya örtülü şekilde de olsa Acaristan'a desteğini devam ettirdiği sürece Acaristan'ın Gürcistan ile arasındaki gerginliğin devam edeceği değerlendirilmektedir.

\section{Türkiye, Azerbaycan ve Gürcistan İttifakının Bölgesel Güvenliğe Etkileri}

Güney Kafkasya'da bulunan Azerbaycan, Gürcistan ve Ermenistan çeşitli iç sorunlar yaşanmaktadır. Azerbaycan yıllardır topraklarından koparılan Dağlık Karabağ bölgesinin kendisine bağlanmasının özlemini yaşarken, Gürcistan ise Gürcistan'dan farklı bir etnisite ihtiva eden bölgelerin Gürcistan'dan ayrılmak istemeleri nedeniyle çeșitli sorunlarla karşı karşıyadır. Gürcistan, ülkesinde işgal ettiği topraklar nedeni ile Rusya ile diplomatik ilişsilerini kesmiş, ancak ticaret, iletişim ve göçmen işçi vizeleri konusunda işbirliğini yeniden başlatmıştır (Yılmaz, 2017). Ermenistan ise tamamen izole durumdadır. Azerbaycan ve Türkiye ile yaşadığı siyasi sorunlar yanında ekonomik sorunlarla mücadele etmektedir. Her üç Güney Kafkasya devleti de Sovyetlerin dağılmasından sonra Rusya'nın etkisinden kurtularak NATO ve ABD'yi kullanarak Batı'ya yaklaşma çabası içine girmişlerdir (Hasanoğlu ve Cemilli, 2006, s. 100).

Rusya Gürcistan ve Ermenistan'da bulunan üslerini koruma ve bölgenin Rusya ekseninden uzaklaşmasını engelleme çabası içindeyken, ABD ise Kafkaslar'a yerleşme arzusundadır. Bu çerçevede Gürcistan geçmiște olduğu gibi, şimdi de büyük güçlerin çatışma alanı olmaya devam etmektedir. Bölgedeki bir diğer sorun da ülkelerde meydana gelen ayrılıkçı iç çatışmalar, darbeler ve siyasi krizlerdir. Söz konusu sorunlar uluslararası odakların olaylara müdahalesi sonucu daha fazla çözümsüz hale gelmektedir. Söz konusu devletlere demokrasiye geçişte de çeşitli sorunlarla karşılaşmaktadır. Ayrıca bu devletlerin halkları Sovyetlerin dağılmasına kadar geçen süreçte kendi ülkelerinin yönetimine katılmak ve bunun sorumluluğunu almaktan çok uzak kalmışlardır (Özsoy, 2006, s. 164-166).

Güney Kafkasya'daki üç devlet halen büyük güçlerin etki ve baskısı altında milli bağımsızlıklarını ve dış politika önceliklerini korumaya çalışmaktadırlar. Üç ülkeden her biri farklı dış politikaya sahiptir. Gürcistan, ABD'ye daha yakınken, Ermenistan; Rusya yanlısı politikalar izlemektedir. Azerbaycan ise büyük güçler arasında daha dengeli bir politika uygulamakta ve Türkiye ile ilişkilerini en üst seviyeye çıkarmaktadır. Rusya ise hayati olarak gördüğü Güney Kafkasya bölgesine üçüncü tarafların müdahale etmesine 
engel olmak ve bölgede etkisini artırmak amacıyla çeşitli politikalar geliştirmektedir ((Kanbolat, 2001, s. 166-167).

Gürcistan, BDT'na girmeye karşı olan bir ülke iken, ayrılıkçı hareketler ve iç savaş sonucu 1993 sonunda BDT’ye girmiş ve Kolektif Güvenlik Anlaşması'nı imzalamıştır (The Europe World Book, 1997). Bu dönemde Gürcistan, Rusya ile “BDT’nin güvenliğini sağlamak maksadıyla" Gürcistan'da Rus üslerinin kurulmasını öngören bir anlaşma imzalamıştır. Abhazya ve Güney Osetya ise Rus-Gürcü askeri işbirliğinin bölgede gerilimi artıracağını ileri sürerek bu antlaşmaya karşı çıkmışlardır. Ekonomik, jeopolitik etkenlerin yanı sıra ülkede giderek kuvvetlenen milliyetçi ve ayrılıkçı hareketler Gürcistan'ı Rusya ile işbirliğine itmiştir. Giderek ülkede Rusya'nın etkisinin artmasına karşın bu durumu dengelemek maksadıyla Gürcistan, Nisan 1996'da Ermenistan ve Azerbaycan ile dostluk ve işbirliği antlaşmaları imzalamıștır. Bunun yanında işbirliğini artırmak maksadıyla Gürcistan, AB üyeleri ve Türkiye ile ikili antlaşmalar imzalayarak Rusya'ya olan bağını azaltmaya çalışmıştır. Gürcistan, yeraltı enerji kaynakları açısından fakir bir ülkedir. En büyük ticaret ortağı $\mathrm{AB}$ olan Gürcistan'ın en çok ticaret yaptığı ülke ise Türkiye'dir. Gürcistan, Karadeniz kıyllarındaki limanları, Hazar-Karadeniz, HazarTürkiye güzergâhındaki kara ulaşımı bağlamında dünya ticareti için önemli bir konumdadır. Gürcistan diğer ülkelere oranla bu avantajlarına rağmen, barındırdığı çeşitli etnik unsurlarla da bir o kadar dezavantaja sahiptir. Gürcistan, ülke bütünlüğüne yönelik bu sorunlara karşı siyasi ve ekonomik tedbirler almadığı takdirde gelecekte giderek küçülüp, sadece Tiflis'e sıkışmış bir devlet haline gelebilir (Kantarcl, 2011, s. 234). Ermenistan, Avrupa'nın en fakir üçüncü ülkesi iken Azerbaycan, 2000'lerden itibaren dünyanın en hızlı gelișen ekonomileri arasında yer almıştır. 1993'te Azerbaycan'da iktidara gelen Haydar Aliyev, ülkenin petrol ve gaz zenginliğini başarılı şekilde kullanmaya başlamış ve ABD ile diğer büyük enerji şirketlerinin ilgisini çekmiştir. Hazar Denizinin Rusya, Azerbaycan, İran, Türkmenistan ve Kazakistan olmak üzere beş ülkeye kıyısı vardır. Hazar Denizi'nin statüsüyle ilgili sorun kıyıdaş ülkelerin müzakereleri neticesinde çözülmüş ve ülkelerin paylarına düşen bölgeler belirlenmiştir. Bir kısım bölge ise ortak kullanım için tanımlanmıştır. BTC projesi ile başlayan boru hatları çalışmaları devam etmiş; ancak petrol ve gaz gelirleri beklenen düzeye ulaşamamıştır (Yılmaz, 2017).

Her üç Güney Kafkasya devleti incelendiğinde çeşitli ekonomik, sosyal ve güvenlik sorunlarıyla karşı karşıya kaldıkları görülmektedir. Bölgesel güç olan Türkiye, Soğuk Savaş sonrasında Güney Kafkasya ülkeleriyle ekonomik ve siyasi ilişkilerini geliştirmeye çalışmıştır. 2017 yılı sonunda Türkiye-Azerbaycan diş ticaret hacmi 2,6 milyar dolar civarında gerçekleşmiștir. Bu dönemde Türkiye'nin Azerbaycan'dan ithalatı yüzde 20,6 artarak 1.366,3 milyon dolar, Türkiye'nin Azerbaycan'a ihracatı ise yüzde 7,8 artarak 1.273,7 milyon dolar olmuştur. Türkiye Gürcistan ile ekonomik ilişkilerini her geçen gün artırmaktadır. 2017 sonu Türkiye-Gürcistan dış ticaret hacmi \%29 artarak 2.728 milyon dolar olarak gerçekleşmiştir. Aynı yıl ithalat da \%9.4 artarak 7979.2 milyon dolara yükselmiștir (T.C. Ticaret Bakanlığı, 2018). Ermenistan ile Türkiye arasındaki sorunlar nedeniyle ekonomik ilişkiler gelişmemiştir.

Sovyetler Birliği'nin dağılmasından sonra Kafkaslar ve Orta Asya'da oluşan güç boşluğunu doldurmak için Rusya Federasyonu, İran ve Türkiye gibi bölgesel güçler bir mücadeleye girmişlerdir (Howard, 1998, s. 170). Başlangıçta hazırlıksız olsa da geçen süreçte Türkiye başta Azerbaycan olmak üzere bu bölgeyi bir açlım alanı olarak görmüştür. Türkiye, Güney Kafkasya bölgesini Türk dünyası ile arasında bir köprü olarak değerlendirmiştir. Soğuk savaş sonrasında Türkiye için bölgesel güç olma politikaları ivme kazanmış ve Türk dünyası kurma idealleri canlanarak yoğun bir şekilde gündeme damgasını vurmuştur (Demir, 2006, s. 43). Ancak Rusya eski arka bahçesi olan Kafkasya'da bu politikanın başarılı olduğunu söylemek pek mümkün değildir (Demir, 2006, s. 45). 
Türkiye Ermenistan ilişkileri çeşitli sorunlar nedeniyle olumsuz olarak etkilenmektedir. Bunların başında Ermenilerin soykırım iddiaları gelmektedir. Soykırım iddiaları, Türkiye-Ermenistan ilișkilerini olumsuz etkilemenin yanında, meclislerinde bu iddiayı yasa tasarısını olarak kabul eden ülkelerle de ilişkiler olumsuz olarak etkilenmektedir (Demir, 2006, s. 46). Ermenistan'ın Dağlık Karabağ’ı işgalinden sonra Azerbaycan ve Türkiye Ermenistan'a ambargo uygulamaktadırlar. Bu durum kaynakları ve üretim düzeyi düşük olan Ermenistan'ı kapalı bir ekonomi haline getirmiştir. Ermenistan, gerek Gürcistan'a karşı Rusya ile olan ittifakı, gerekse bu ittifak karşısında yükselen Gürcü milliyetçiliği nedeniyle bölgede milliyetçiliği körüklemektedir (Kasım, 2011, s. 58). Bunun yanında Ermenistan'ın Azerbaycan ve Türkiye'ye karșı takındığı tutum da Ermeni milliyetçiliğini yükseltmektedir. Ayrıca diaspora Ermenileri de tüm dünyada Ermeni milliyetçiliğinin artmasına katkı sağlamaktadırlar. Yukarıda belirtilen nedenlerden dolayı Ermenistan'ın Azerbaycan ve Türkiye tarafından ambargoya maruz kalması, ülkeyi ekonomik ve güvenlik açısından Rusya eksenine yönlendirmektedir. Geçen süreçte Ermenistan, güvenlik bakımından Rusya'ya bağımlı bir hale gelmiş ve iki ülke arasındaki ilișki müttefiklik ilișkisine dönüșmüștür. Ancak Ermenistan'ın Rusya ile doğrudan karasal bağlantısının bulunmaması sorun yaratmakta ve Ermenistan'ın kaderini Rusya-Gürcistan ilişkilerinin durumuna bağımlı hale getirmektedir (Veliev, 2011, s. 116).

Azerbaycan-Türkiye-Gürcistan arasında oluşturulan üçlü işbirliği temelde bir güvenlik ve askeri işbirliği mekânizması değildir. Ancak, üç devlet arasında oluşturulan karşılıklı bağımlılık ilișkisi çerçevesinde üçlü işbirliğinin güvenlik alanına da birtakım yansımaları olmuştur. Bu işbirliği Güney Kafkasya bölgesini bir güvenlik bölgesi olması için büyük önem taşımaktadır. Bu kapsamda bölgede karşlaşılan benzer güvenlik sorunları ve tehditlere karşı ortak çıkarlar temelinde ortak çözümler geliştirilmeye çalışılmaktadır. Bölgedeki her bir ülke bir diğerini stratejik ortak olarak değerlendirmekte, güvenlik ve savunma doktrinlerinde dikkate almaktadır. 2011 yılı sonunda kabul edilen Gürcistan Ulusal Güvenlik doktrininde Türkiye, bölgedeki tek NATO üyesi ülke, bölgenin lider devletlerinden biri ve önemli askeri müttefiki olarak tanımlanmıștır. Doktrinde, Gürcistan'ın Türkiye ile güvenlik ve savunma alanındaki ilişkilerini daha da geliştirmeye önem verdiği belirtilmektedir. Aynı belgede, Azerbaycan da stratejik ortak olarak tanımlanmaktadır (İsmayll, 2012).

Türkiye, bölgedeki sorunların çözümünde ortak olarak her üç devletin yanında uluslararası toplumu da almak istemektedir. Güvenlik açısından bu yaklaşım üçlü işbirliğini gerekli kılmaktadır. Söz konusu işbirliği kısa vadede bir askeri ittifak kurulmasına yol açmasa da ortaya çıkan/çıkabilecek tehditlere karşı bölgenin güvenliğini sağlamak açısından önemlidir. Bölge devletlerinin imzalamış oldukları belgelerde güvenlik açısından üç alanda ișbirliği öngörülmüștür. Bunlar, bölge devletlerinin egemenliklerinin ve bağımsızlıklarının muhafaza edilmesi; ayrılıkçılık ve toprak bütünlüğüne karşı tehditlerle mücadelede işbirliği ile geleneksel olmayan güvenlik tehditlerine karşı işbirliği yapılmasıdır. Özellikle egemenlik ve bağımsızlık vurgusu toprakları dış devletler tarafından işgal edilmiş olan Azerbaycan ve Gürcistan için önemlidir. Bunun yanında işbirliğinin üçlü düzeye çıkarılması için çeşitli askeri tatbikatları da içeren çeşitli anlaşmalar gerçekleştirilmektedir. Bu kapsamda Azerbaycan, Türkiye ve Gürcistan tarafından Nahcivan'da 19 Ağustos 2014 tarihinde imzalanan ve ortak askeri tatbikatlar gerçekleştirmeyi öngören anlaşma ile güvenlik alanında üçlü düzeyde işbirliği kurulmuştur. Anlașma ile her üç ülkenin silahlı kuvvetlerinin muharebe kabiliyetlerinin geliştirilmesi hedeflenmiştir. Üç ülke özel kuvvetleri, ilk üçlü askeri eğitim faaliyetini Kasım 2012'de düzenlenen "Kafkas Kartalı 2012" adlı bir askeri tatbikat ile gerçekleştirmişlerdir. Mayıs 2016 tarihinde gerçekleştirilen Azerbaycan, Gürcistan ve Türkiye'nin katılımıyla yapılan üçlü toplantıda üç ülkenin askeri becerilerini ve hazırlık 
durumunu arttırmak amacıyla ortak tatbikat gerçekleştirilmesinin uygun olacağına karar verilmiștir. Ayrıca siber güvenlik, petrol ve doğalgaz boru hatlarının korunması konusunda da işbirliği yapılması gerektiğine vurgu yapılmıștır. Bu kapsamda ortak tatbikatlar yapılmasına karar verilmiştir. Azeri, Türk ve Gürcü silahlı kuvvetlerinin katılımıyla ortak askeri tatbikatlar gerçekleștirilmesine karar verilmiştir. Bu kapsamda Gürcistan'da gerçekleștirilen Türkiye, Azerbaycan ve Gürcistan askerlerinin katıldığı "Eternity-2017" ortak askeri tatbikatı başarıyla gerçekleştirilmiştir. Nisan 2018 tarihinde Türkiye, Azerbaycan ve Gürcistan arasında imzalanan işbirliği memorandumuyla üç ülke arasındaki askeri işbirliğinin son yıllarda daha çok önem kazanmıştır. İşbirliği teorik düzlemde bırakmayıp, pratik zemine de taşınmıştır. Askeri alanda ortak tatbikatların düzenlenmesine bir kez daha vurgu yapılmıștır. Azerbaycan ve Gürcistan askerlerinin NATO üyesi Türk askerlerden eğitim görmesinin önemine vurgu yapılmıştır. Ayrıca bu üç taraflı işbirliğinin, her üç ülkenin silahlı kuvvetlerini uluslararası terörizmle, silah ve uyuşturucu madde kaçakçılığıyla ortak mücadele için hazırlamaya yönelik olduğu da ifade edilmiștir. Daha sonra Türkiye, Azerbaycan ve Gürcistan Milli Savunma Bakanlarının katılımı ile 6'ıncı Savunma Zirvesi Giresun'da gerçekleştirilmiştir. NATO'nun desteğiyle Gürcistan'da 4'üncüsü düzenlenen "Noble Partner 2018" çok uluslu askeri tatbikatının başkent Tiflis'e yakın Vaziani askeri üssünde gerçekleștirilmiștir. Söz konusu tatbikata Türkiye, Gürcistan, ABD, İngiltere, Almanya, Estonya, Fransa, Litvanya, Polonya, Norveç, Ukrayna, Azerbaycan ve Ermenistan katılmıștır. Müzakereler ile savunma bakanlarının yılda iki defa görüşmesi, ortak konferanslar ve yuvarlak masa toplantıları düzenlenmesi, üç taraflı askeri eğitim ve işbirliği mekânizmaları oluşturulması hedeflenmiștir. Bu kapsamda bașta NATO ve ilgili diğer güvenlik örgütleri olmak üzere çeşitli Batılı örgütlerle ve aktörlerle daha yakın işbirliğine gidilmesi kararlaştırılmıştır. Türkiye, Gürcistan ve Azerbaycan'ın NATO ile ișbirliği geliștirmesinde belirleyici bir konumdadır. Azerbaycan ve Gürcistan arasında 1994 yılında imzalanan BíO işbirliği çerçevesinde NATO ile ilişkiler başlamıştır. Bu ilişki, Azerbaycan ve Gürcistan askeri birliklerinin Kosova ve Afganistan'da Türk komutasında görev yapmalarıyla pekișmiștir. Türkiye, her iki ülkede askeri okullar kurarak bu ülkelerin askeri birliklerini eğitmiștir. Askeri sanayi alanında da üçlü bir işbirliği geliştirilmeye çalışılmaktadır. Bölgedeki üçlü işbirliğine diğer bölge ülkeleri de dâhil edilmeye ve Güney Kafkasya bir barış bölgesi haline getirilmeye çalışılmaktadır. Türkiye ve Azerbaycan aralarında geliştirdikleri işbirliğinin İran ve Rusya'ya karşı olmadığını her fırsatta ifade ederlerken, Gürcistan söz konusu işbirliğinin Ermenistan'a karşı kurulmadığını, bölge devletleri ile iyi ilişkilerin geliştirilmesinin hedeflendiğini belirtmektedir.

\section{Sonuç ve Öneriler}

Güney Kafkasya bölgesi, hem bölgedeki kritik enerji kaynakları hem de Orta Asya'ya geçiş kapısı olması nedeniyle tüm dünyanın dikkatini çeken bir coğrafya olmuştur (Aslanlı, 2011). Güney Kafkasya bölgesi ülkelerinden Gürcistan'ın kritik coğrafi konumu, Azerbaycan'ın ekonomik potansiyeli ve doğal kaynakları, Ermenistan'ın Rusya ile kurmuş olduğu askeri işbirliği tüm dünyanın ilgisini bu bölgeye çekmektedir (Cabbarlı, 2003, s. 15-16). Ayrıca Güney Kafkasya, Türkiye için Doğu Anadolu Bölgesinin savunması ve güvenliğinin sağlanması açısından büyük önem taşımaktadır. Ayrıca bölge, Orta Asya ve İdil-Ural bölgesindeki, Türk ve Müslüman ülke ve topluluklar ile bağlantısını sağlaması ve ilişkilerini güçlendirmesi dikkate alındığında büyük öneme sahiptir. Bölgenin stratejik yeraltı zenginlikleri ve petrol yataklarına sahip olması, uygun hammadde ve pazar olanağı oluşturması da dünyanın dikkatini bu bölgeye çevirmektedir. Bunun yanında bölge Rusya'nın güneye sıcak denizlere ulaşmasının engellenmesi ve Türkiye için tehdit olmaktan çıkartılması gibi temel konularda, avantajlar sağlayacak bir bölgedir (Alizade, 
2015, s. 8). Türkiye açısından Anadolu topraklarının uzantısı ve tamamlayıcısı olarak kabul gören Kafkaslarda cereyan eden her türlü olay, Türkiye'yi doğrudan etkileme potansiyeline sahiptir. Ayrıca Kafkasya bölgesi Türkiye ile zengin enerji kaynaklarına sahip Orta Asya Türk devletleri arasında bir köprü vazifesi de görmektedir. Bu özelliğiyle bölge Türkiye açısından vazgeçilemeyecek bir coğrafya olarak kabul edilmektedir (Tanrısever, 2015, s. 240). Türkiye, 1990'ların başında bağımsızlıklarını kazanan Güney Kafkasya devletleri ile siyasi, ekonomik ve sosyal ilişkilerini geliştirmektedir (Oran, 1995, s. 271-278). İlham Aliyev'in iktidara gelmesiyle birlikte Türkiye ile Azerbaycan arasındaki ilişkiler en üst seviyeye gelmiştir. Azerbaycan ve Gürcistan arasındaki ilişkiler özellikle ekonomi kalkınma ve enerji projelerinin uygulanmasında stratejik ortak olacak kadar iyidir. Gürcistan, Azerbaycan petrolü için geçiş bölgesidir. Türkiye, Azerbaycan ve Gürcistan ile kurmuş olduğu bu yakın iliş̧ilerini güvenlik alanına da taşımak istemektedir. İlişkilerin gelişmesiyle birlikte Azerbaycan, Gürcistan ve Türkiye arasında kurulan üçlü işbirliği kısa bir sürede somut program ve projelerle desteklenerek stratejik ortaklık düzeyine ulaşmıştır. Üç ülkenin ilgili bakanlık, kurum, kuruluş ve yetkilileri düzenli aralıklarla bir araya gelerek hedefler belirlemektedirler. Düzenli aralıklarla yapılan bu görüşmeler ve toplantılar neticesinde üç ülke arasındaki ilişkiler kurumsallaşmış ve belirlenen hedeflerin gerçekleşip gerçekleşmediğini değerlendirildiği mekânizmalar oluşturulmuştur. Üçlü cumhurbaşkanları, dışişleri bakanları, ekonomi bakanları ve savunma bakanları toplantılarının yanında devlet kurumlarını ve özel sektör temsilcilerini bir araya getiren üçlü iş konseyi toplantıları da belirli aralıklarla yapılmaya başlanmıștır. Böylece Türkiye-Gürcistan-Azerbaycan arasında oluşturulan üçlü mekânizma vasıtasıyla Kafkasya'nın bir barıș, istikrar ve refah sahasına dönüşmesinin sağlanmıştır. Ayrıca oluşturulan üçlü mekânizmanın Ermenistan'ı dışladığı yönündeki eleştiriler reddedilmekte ve barışçıl çözümü destekleyecek adımları atması halinde oluşumun Ermenistan'a da açık olduğu vurgulanmaktadır. Ermenistan'ın işgal ettiği bölgelerden çekilmesi, Türkiye ile olan sınırını tanıması ve sözde Ermeni soykırımı söylemlerinden vazgeçmesi hem bölgesel anlaşmazlıkların çözümü, hem de barıș, istikrar ve refah içerisinde bir Kafkasya'nın oluşumuna büyük bir katkı sağlayacaktır. Ancak Ermenistan'ın halen devam ettirdiği uzlaşmaz ve işgalci tutumu nedeniyle Ermenistan'ın yakın dönemde bu oluşumun içinde olamayacağını göstermektedir.

Türkiye, Gürcistan ve Azerbaycan arasındaki ilişkilerinin stratejik bir düzeye ulaşmasındaki itici güç ekonomik ilişkiler olmuştur. Özellikle enerji alanındaki işbirliği BTC, BTE ve TANAP gibi uluslararası dev projelerle derinleşerek ekonomik bağlamda ülkeleri birbirlerine bağlamıștır. Ayrıca enerji alanında başlayan işbirliği ulaşım ve iletişim alanlarıyla desteklenerek daha karmașık ve etkin bir stratejik ișbirliğine dönüşmüştür. Bu kapsamda Avrupa ve Asya'yı birbirine bağlayacak olan ve Demir İpek Yolu olarak değerlendirilen BTK demiryolu projesi büyük önem taşımaktadır.

Sonuç olarak, Güney Kafkasya'da Azerbaycan, Gürcistan ve Türkiye arasında giderek derinleșen ve boyutlanan üçlü ișbirliği, oluşturulan mekânizmalar ile ekonomiden güvenliğe kadar çok çeşitli alanlarda üç ülkenin ortak çlkar ve beklentilerine hizmet etmektedir. Bu ortamda Türkiye, Güney Kafkasya'ya yönelik çıarları çerçevesinde Azerbaycan ve Gürcistan ile her alanda işbirliği yapmakta ve Rusya Federasyonu ile arasında bir "Barış Kuşağı" oluşturarak bölgesel güvenliğe katkı sağlamaktadır. 


\section{KAYNAKÇA}

ABBASLI, N. (2011). Yüzyılın Soykırımı Hocalı. İstanbul: Bilge Karınca Yayınları. AKBULUT ÖZPAY, G. (2018, Ocak). Bakü-Tiflis-Kars Demiryolu ve Türkiye Açısından Jeopolitik Önemi. Marmara Coğrafya Dergisi. S. 37 (103-111). s. 103. AKGÜN, M. (1998). Türkiye'den Bakarak Türk-Rus İlișkileri. YALÇINKAYA, A. (Ed.) Türk Cumhuriyetleri ve Petrol Boru Hatları. s. 217.

ALIZADE, N. (2015). Güney Kafkasya'da Etnik Çatıșmalar ve Bölgenin Türkiye İçin Önemi. Akademik Perspektif. Erişim Tarihi: 12.04.2019, http://akademikperspektif. com/2015/04/13/guney-kafkasyada-etnik-catismalar-ve-bolgenin-turkiye-icin-onemi/

ALPARGU, S., SAHIN, E. (2007). Sovyet Rusya'nın Dağılmasından Sonra Kafkasya'da Kimlik Problemi. Akademik İncelemeler, Cilt:2. Sayı:1. 326-345.

ASLANLI, A. (2001). "Tarihten Günümüze Karabağ Sorunu”. Avrasya Dosyası. Cilt 7. Sayı 1. 394-430.

AYDIN, M. (2004, Yaz). Foucault's Pendulum: Turkey in Central Asia and the Caucasus. Turkish Studies. Cilt 5. Sayı 2. 1-22.

CABBARLI, H. (2004). Bağımsızlık Sonrası Ermenistan Rusya Illişkileri. Ankara: ASAM Yayınları.

CABBARLI, H. "Dağlık Karabağ Sorununun Çözümünde Son Gelişmeler”, Erişim

Tarihi: 11.06.2007,

http://www.azsam.org/modules.php?name=News\&file=print\&sid=88

CAFERSOY N. (2001). Elçibey Dönemi Azerbaycan Dış Politikası. Ankara: ASAM Yayınları.

DEMİR, A. F. (2003). Türk Dış Politikası Perspektifinden Güney Kafkasya. Ankara: Bağlam Yayıncılık.

DEMİR, A. F. (2006). Türkiye'nin Güney Kafkasya Politikası. Yenilevent-İstanbul: Harp Akademileri Basımevi.

DIKKAYA, M., TIĞLI, A. (2015). Güney Kafkasya Enerji Koridoru, Alternatif Projeler Kapsamında, TANAP. Gaziosmanpaşa Üniversitesi Sosyal Bilimler Araștırmaları Dergisi, (Yaz 2015) 10/1. 99-117.

ELVAN, D. (2006). Kafkasya'da Patlamaya Hazır Etnik Bomba: Gürcistan'da Özerklik Sorunları. Adnan Menderes Üniversitesi, Nazilli İktisadi ve İdari Bilimler Fakültesi, Uluslararası İlişkiler Anabilim Dalı.

ERTAȘ, U. (2009). "Güney Osetya Raporu”, TUIC Akademi, Erișim tarihi:

10.10.2018 http://www.tuicakademi.org/guney-osetya-raporu/

GÜRSES, E. (2001, İlkbahar). Kafkasya'da Uluslararası Rekabet. Avrasya Dosyası Azerbaycan Özel. Cilt 7. Sayı 1. 250-273.

HACISALİHOĞLU, Y. (2006). “Jeopolitik Düzlemde Güney Kafkasya”, Harp

Akademileri Basımevi, Yenilevent-İstanbul.

HASANOĞLU, M. ve CEMİLLİ, E. (2006), Güney Kafkasya'da ABD Politikası, IQ

Kültür Sanat Yayıncılık, İstanbul.

HOWARD, G. (1998). NATO and Caucasus: The Caspian Axis. Carlisle: SSI

İSKENDER, S. (2007). Dünya Enerji Merkezi Hazar Üzerindeki Güç Kavgaları.

Dünya. 20.02.2007.

İSMAYIL, E. Gürcistan'ın Yeni Ulusal Güvenlik Konsepti. (13.02.2012). BILGESAM,

Erişim tarihi: 10.10.2018, http://www.bilgesam.org/incele/166/gurcistan $\%$ E2\%80\%99in-yeni-ulusal-guvenlik-konsepti/\#.W9WEaGgzbIU

İŞYAR, Ö. G. (2006). “Türkiye'nin Azerbaycan-Ermenistan Uyuşmazlığına Yönelik Politikaları:1992-1994”. Yelda DEMIRAĞ, Y., KARADELİ, C. (Ed).Geçmişten Günümüze Dönüșen Orta Asya ve Kafkasya. Ankara: Palme Yayıncılık. 
KALKAN, D. (2010). Güney Kafkasya Bölgesi'ndeki Etnik Çatışma Alanlar (Yayınlanmış Yüksek Lisans Tezi). Selçuk Üniversitesi Sosyal Bilimler Enstitüsü Uluslararası İlişkiler Anabilim Dalı, Konya.

KANBOLAT, H. (2001). "RF'nin Kafkasya Politikası ve Çeçenistan Savaşı”, Avrasya Dosyası, Ankara: ASAM Yayınları, Cilt 6, Sayı 4,s.165-179.

KANBOLAT, H. (2003). Avrasya İşbirliği Eylem Planı: Türkiye ile Rusya Federasyonu Arasında Yeni Bir Dönem Mi?. Stratejik Analiz. 50-52. Yayıncılık.

KANTARCI, H. (2006). Kıskaçtaki Bölge Kafkasya, İstanbul: IQ Kültür Sanat

KARAYEL, Erol (1998), "Kafkasya'da Etnik Çatıșmalar: Sebepler ve Çözümler”, Kafkas Vakfi Bülteni, Kıș, Erişim tarihi: 10.10.2018,

http://www.kafkas.org.tr/bgkafkas/etniksorunlar.html

KAŞIKÇI, N., Yılmaz, H. (1999). Aras'tan Volga'ya Kafkaslar (Ülkeler-Şehirler-İz Bırakanlar). Ankara: Türkar Yayınları.

KOÇAK, K. A. (2018). Hazar Denizinin Statüsüne Dair Anlaşma ve Olası Yansımaları. TASAV Dış Politika Araștırmaları Merkezi. s. 1.

KOÇOĞLU, M. (2001). Ekostratejik yönüyle Kafkasya Bölgesini değerlendiriniz ve Türkiye için önemini belirtiniz, Yayınlanmamış Akademi Tezi, Harp Akademileri Yayını, İstanbul.

KUMUK, C. (2004). Kafkasya Aydınlık Günlerini Arıyor. Neredesin Prometheus?, İstanbul: AlfaYayınları.

KUZLOVA, M. (2005). GUUAM Reacts to Uzbek Withdrawal. RFE/RL, Erişim tarihi: 17.10.2018, http://www.rferl.org/content/article/1058766.html

MERT, O. (2004). Türkiye'nin Kafkasya Politikası ve Gürcistan, İstanbul: IQ Kültür Sanat Yayıncılık.

NICHOL, J. (2008). "Russia-Georgia Conflict in South Ossetia: Context and Implications for U.S. Interests”, Erişim Tarihi: 08.12.2018,

http://www.fas.org/sgp/crs/row/RL34618.pdf

OĞAN, S., AĞACAN, K. (2001). “Güney Kafkasya'da Yeniden Başlayan veya Bitmeyen Soğuk Savaş”, Stratejik Analiz, Cilt 2, Sayı 13. 25-27.

OZHIGANOV, E. (1997). "The Republic of Georgia: Conflict In Abkhazia and South Ossetia”. ARBATOV, A., CHAYES, A., HANDLER CHAYES, A., OLSON, L. (Ed), Managing Conflict In The Former Soviet Union: Russian and American Perspectives, London: The MIT Press.

ÖZSOY, İ. (2006). "Sovyet Sisteminin Çöküşünden Tarihi ve Evrensel Dersler”, BILIGG, Güz, Sayı 39: 163-194.

PIRTAKHIA, A. (2005). Avrasya Koridorunda Gürcistan'ın Önemi ve Bu Koridorun Güvenliğinin Sağlamasında Gürcistan İç Kuvvetlerinin Rolü, Yayınlanmamıș Akademi Tezi, Harp Akademileri Yayını, İstanbul.

SEKIN, S. ve TEKIN, R. (2006). "Güney Kafkasya ve Gürcistan”, Kafkasya

Araştırma\&Analiz Dergisi, İstanbul: Kafkas Vakfı Yay., Yıl 1, Sayı 2, s.28-38.

SEVER, A. (2001). Türkiye-Rusya Federasyonu ilişkilerinde Çatışma, Rekabet ve İșbirliği. Avrasya Dosyası Özbekistan Özel. Cilt 7. Sayı 3. 241-242.

TAȘTEKIN, F. (2002). "Abhaz-Gürcü Sorununun Kilit Vadisi: Kodor”, Kafkas Vakfi Raporu:5, Kafkas Vakfi Yayınları, İstanbul, Erişim tarihi: 18.02.2019, http://www.kafkas.org.tr/hakkinda/kodor.pdf.

TAVKUL, U. (2008). “Güney Osetya Meselesinin Perde Arkası”, Erişim tarihi: 10.10.2018, http://www.koksav.org.tr/ebulten/eyl-ekkas2008/081127 hk utavkul gom.html 
Doğan Şafak Polat, “Kafkasya'da Türkiye, Azerbaycan ve Gürcistan İttifakının Bölgesel Güvenliğe Etkileri”, İstanbul Gelişim Üniversitesi Sosyal Bilimler Dergisi, 6 (2), Ekim 2019, ss. 248-265.

T.C. Dıșişleri Bakanlığı (2018). “Güney Kafkasya Ülkeleri İle İlişkiler”, Erişim tarihi: 10.10.2018, http://www.mfa.gov.tr/turkiye_nin-guney-kafkasya-ulkeleriyleiliskileri.tr.mfa

T.C. Enerji ve Tabii Kaynaklar Bakanlığı, Doğalgaz Boru Hatları ve Projeleri. Erişim tarihi: 10.10.2018, https://www.enerji.gov.tr/tr-TR/Sayfalar/Dogal-Gaz-BoruHatlari-ve-Projeleri

T.C. Ticaret Bakanlığı (2018), “Gürcistan'ın Dıș Ticareti Artıyor”, Erişim tarihi: 10.01.2019, https://www.ticaret.gov.tr/blog/ulkelerden-ticarihaberler/gurcistan/gurcistan-in-dis-ticareti-artiyor

The Europe World Book (1998). Georgia: Introductory Survey. Europa Pub. Ltd. Vol. I. 1386-1387.

TRACECA Genel Sekreterliği (2010). The Silk Road of the 21st Century. Erișim tarihi: 17.10.2018, http, s.//www.traceca-org.org/en/home/the-silk-road-of-the-21stcentury/

ÜZÜMCÜ, A., AKDENIZ, S. (2014). Yeni İpek Yolu: TRACECA ve Bakü-Tiflis-Kars Demiryolu Projesi. Avrasya Etüdleri 45/2014-1 (171-199), s.1.

World Bank (2008). Migration and Remittances Factbook, Washington, DC: World Bank.

YALÇINKAYA, A. (2006). Kafkasya'da Siyasi Gelișmeler: Etnik Düğümden Küresel Kördüğüme, Ankara: Lalezar Kitabevi Yayınları.

YAPICI, M. İ. (2007). "Kafkasya'nın Sorunlu Bölgesi: Güney Osetya”, Orta Asya ve Kafkasya Araștırmaları Dergisi, Cilt.2, Sayı.3.

\section{Summary}

The Caucasus region covers east of the Caspian Sea, the Black Sea, the Azov Sea in the west, Manic river and marshes in the North, Iran in the south, and also covers a geographical area which is surrounded by Turkey. Throughout the history, in addition to creating trade and migration routes, the Caucasus has been an important crossroads where cultures cross. Being a bridge between East and West and located in the most sensitive part of the Eurasian geography, the Caucasus is attracting not only the attention of the whole world in terms of political and economic aspects, but also the struggle of many power focuses. In this respect, the Caucasus has served as a corridor and asylum between northsouth and east-west throughout history. The region is referred to as two regions, North and South Caucasus. The North Caucasus region consists of Karachai-Cherkessia, KabardinoBalkaria, Chechnya, Ingushetia, Dagestan, Ossetia, Adygea and Abkhazia. The South Caucasus or Transcaucasia in the north, starting from the Black Sea to the northeast, Azov is located in the coast of the Caspian Sea with the Sea along the lines up to Baku, south of Iran, east of the Caspian Sea and west from Turkey. The region consists of three states, Georgia, Azerbaijan and Armenia. In addition, these states include the autonomous regions of South Ossetia and Nagorno-Karabakh and the Autonomous Republics of Abkhazia, Nakhichevan and Ajaristan.

In terms of its strategic location and underground energy resources, The South Caucasus region is one of the most important geographies in the world. Although Turkey has a land border with the South Caucasus region, NATO ally Turkey's relations with the countries in the Soviet Union remained very limited during the Cold War. On 8 December 1991, the international system was radically changed, with the official disintegration of the Soviet Union and thus the end of the Cold War. Turkey unprepared for this change, initially did not react immediately, and did not show the desired level of relations with the countries. The hypothesis of this study is that "Turkey's development of economical and social relations 
between neighboring South Caucasus states and also the expansion of these relations so as to cover security dimension will contribute positively to regional security."

The study consists of three parts. In the first part, geopolitic importance of the South Caucasus will be emphasized. In the second part, existing problems in the region will be included. In the third part, Turkey, Azerbaijan and Georgia's alliance, and its effects to the regional security will be discussed. 